\title{
Shading EfFects on Greenhouse Microclimate AND Crop Transpiration in a Cucumber Crop Grown Under Mediterranean Conditions
}

\author{
E. Kitta， N. Katsoulas，D. Savvas
}

\begin{abstract}
The aim of this study was to investigate the effects of greenhouse shading on greenhouse microclimate and energy balance, and on crop production. Experiments were carried out in the experimental farm of the University of Thessaly at Velestino, in three similar, plastic-covered greenhouses using hydroponically-grown cucumbers as a test crop. One of the greenhouses was used as a control (without shading); the other two were shaded using two different shade nets (shading intensity of approximately $35 \%$ and $50 \%$, respectively). Climatic parameters were measured during two growing seasons from April to June and from September to November 2008 and seven selected days of the above periods are presented. The results showed that shading could not keep greenhouse air temperature and vapor pressure deficit below $30^{\circ} \mathrm{C}$ and $1.5 \mathrm{kPa}$, respectively, values that are considered acceptable for cucumber crop growth (Growers Books, 1980; Bakker et al., 1987; Olympios and Hanan, 1992). From the crop production data it was found that shading intensity should not exceed 35\%. The analysis of greenhouse microclimate and energy balance showed that shading is necessary from the middle of spring, while even shading of approximately 50\% was not sufficient to cool the greenhouse during noon time of summer days in Central Greece and that an additional cooling system was required.
\end{abstract}

Keywords. Air temperature, Solar radiation, Shade net, Energy balance.

$\mathrm{G}$ reenhouse cooling is a matter of increasing interest for growers in Mediterranean countries, due to excessively high air temperature and vapor pressure deficit levels during summer. These conditions negatively affect crop physiological activities, crop growth, and quality (Jarvis and McNaughton, 1986; Aubinet et al., 1989), crop water status (transpiration and stomatal conductance) and production, and quality characteristics (Abdel-Mawgoud et al., 1996). Various methods can be used to cool the greenhouse. Natural ventilation is one of the most usual practices. However, currently the majority of greenhouses include some type of ventilation system (Boulard et al., 1997; Kittas et al., 1997). Natural ventilation is generally not sufficient for releasing the excess energy during sunny days in summer and, therefore, other cooling methods have to be used in combination with natural ventilation (Katsoulas et al., 2001).

The use of screens, especially the white wash of the cover, is a typical practice in the whole Mediterranean basin. It is considered a low-cost method of decreasing radiation and the

Submitted for review in April 2011 as manuscript number SE 9151; approved for publication by the Structures \& Environment Division of ASABE in October 2011.

The authors are Evaggelini Kitta, Agronomist, Institute of Technology and Management of Agricultural Ecosystems, Center for Research and Technology of Thessaly, Volos, Greece; Nikolaos Katsoulas, Assistant Professor, University of Thessaly, School of Agricultural Sciences, Department of Agriculture Crop Production and Rural Environment, Magnesia, Greece; and Dimitrios Savvas, Accosiate Professor, Agricultural University of Athens, Department of Crop Science, Athens, Greece. Corresponding author: Nikolaos Katsoulas, University of Thessaly, School of Agricultural Sciences, Department of Agriculture Crop Production and Rural Environment, 38446, N. Ionia-Volos, Magnesia, Greece; phone: 00302421093249; e-mail: nkatsoul@uth.gr. concomitant energy load during warm periods. The few studies (Baille et al., 1980; Baille et al., 2001; Mashonjowa et al., 2010) relevant to whitening suggest that white painting of the greenhouse cover material is not only a cheap but also an efficient crop shading method. Greenhouse whitening allows inside air temperature to be maintained close to or even lower than the outside level during summer periods due to an increase of crop transpiration rate under shading (Baille et al., 2001; Mashonjowa et al., 2010) while it reduces the solar infrared fraction that enters to the greenhouse, enhancing slightly the photosyntheticaly active radiation (PAR) proportion in the incoming solar irradiance (Kittas et al., 1999). The latter characteristic of whitening could represent an advantage with respect to other shading options, especially in warm countries with high radiation load during summer. On the other hand, the major disadvantage of whitening is the lack of flexibility, since neither the application of shading nor its level can be adapted to natural changes of solar radiation intensity during the cropping period. Additionally, it is easy to add more but difficult to remove the whitening material at the end of the warm season, when natural solar radiation intensity decreases and shading may restrict crop light perception to critical levels.

Mobile shading allows improvement of greenhouse climate, especially during the noon hour. It reduces canopy transpiration and water uptake, and increases remarkably water use efficiency (Lorenzo et al., 2006). The use of shading screens in greenhouses became a common practice during the last decade (Cohen et al., 2005; Castellano et al., 2008) because it is a flexible and efficient method of reducing the energy load inside the greenhouse (Teitel and Segal, 1995), especially in climates characterized by high evaporative demand and limited water resources (Lorenzo et al., 2006). 
The optical properties of the screens (type of fabric and shade factor) and the whitening of the cover (type of product and concentration) can modify the diffuse-to-direct radiation ratio (Baille et al., 2001; Raveh et al., 2003; Cohen et al., 2005) and cooling performance (Willits, 2001), while reducing air and crop temperature (Smith et al., 1984; Fernandez-Rodriguez et al., 2000). The modifications arising from the optical properties of the screens can affect radiation absorbed by the crop, stomatal conductance, and net assimilation of $\mathrm{CO}_{2}$, and consequently crop growth and productivity. Furthermore, light quality modifications affect morphogenesis and photosynthesis, although their role in growth has not been yet completely clarified (Li et al., 2000). Nevertheless, adaptation of plants to light conditions depends also on the specific behavior of the plant species grown in greenhouses (Raveh et al., 2003; Barradas et al., 2005; Romacho et al., 2006). Shade can increase total and marketable yield of tomato grown in hot climates. Depression of crop yield is frequently observed under Mediterranean conditions when high solar radiation and low air humidity conditions prevail. Tomato plants grown in Egypt for the entire season with under $30 \%$ to $40 \%$ shade produced more fruit thereby rendering a higher yield than those grown without shade (El-Aidy, 1986; Abdel-Mawgoud et al., 1996). Increasing shade intensity to above $40 \%$ decreased flowering and yield. El-Gizawy et al. (1993) observed that increasing shading intensity up to $51 \%$ over a tomato crop resulted in fruit total production increase. The same authors mention that the highest tomato crop production was obtained under $35 \%$ shading, while increasing shading intensity decreased by up to $100 \%$ the incidence of sunscald on fruit. Concerning the effect of shading on cucumber crop, Naraghi and Lofti (2010) observed that increasing shading density up to $35 \%$ led to an increase in the number of fruits per plant. However, the number of fruits tended to decrease as shading density increased to $60 \%$. Furthermore, the above authors mention that shading intensity greatly influenced the physiological disorders like sun-scald of cucumber fruits.

A better understanding of plant responses to shading is of great interest for greenhouse crops. With respect to the Mediterranean greenhouses, more information is needed mainly on plant responses to the time of application, including both commencement and termination of shading dates, degree of shading, and shading technique (whitening products, disposition, and mobility of the screens in the greenhouse).

To our knowledge there is little information in the literature regarding the responses of cucumber crops to greenhouse shading under Mediterranean climatic conditions. Thus, the present work aimed at studying the effect of different shading levels achieved by means of agricultural shade nets, on greenhouse microclimate, energy balance, and crop transpiration under Mediterranean climate conditions.

\section{Materials ANd Methods}

\section{Greenhouse Facilities and Plant Material}

The experimental work was carried out in three similar, single-span, arched roof, greenhouses covered by a single polyethylene film (type PE-EVA-film TUV 3945, film thickness of $180 \mu \mathrm{m}$, Plastika Kritis S.A., Heraklion-Crete, Greece), N-S oriented, located at the experimental farm of the University of Thessaly near Volos (Velestino: Latitude $39^{\circ} 22^{\prime}$, longitude $22^{\circ} 44^{\prime}$, altitude $85 \mathrm{~m}$ ) during spring, summer, and autumn in 2008 (fig. 1). The geometrical characteristics of each greenhouse were as follows: eaves height of $2.4 \mathrm{~m}$, ridge height of $4.1 \mathrm{~m}$, total width of $8 \mathrm{~m}$, total length of $20 \mathrm{~m}$, ground area of $160 \mathrm{~m}^{2}$, and volume of $572 \mathrm{~m}^{3}$. The greenhouses were equipped with two continuous side roll-up windows located at a height of $0.6 \mathrm{~m}$ above the ground with a maximum opening area $A_{T}$ of $27 \mathrm{~m}^{2}$ (two vents of $15 \mathrm{~m}$ length $\times 0.9 \mathrm{~m}$ opening height) for both vents (ratio of opening to greenhouse ground area of about $17 \%$ ). The vents were controlled automatically via a controller (Macqu, Geometions SA, Athens, Greece) and opened in steps; they began to open when greenhouse air temperature exceeded $23^{\circ} \mathrm{C}$, and reached their maximum aperture when temperature reached $28^{\circ} \mathrm{C}$. The prevailing wind of the region had a N-S direction. The greenhouse soil was totally covered by a double-side (black downwards - white upwards) plastic film $200 \mu \mathrm{m}$ thick (Plastika Kritis S.A., Heraklion-Crete, Greece).

During the experimental period, two cucumber crops (Cucumis sativus cv. Stamina) were grown, specifically a spring crop planted on 10 April and terminated on 28 June and an autumn crop planted on 1 September and terminated on 12 November. The plants were grown hydroponically in bags ( $1 \mathrm{~m}$ long, $0.3 \mathrm{~m}$ wide, $0.2 \mathrm{~m}$ high) filled with perlite. The plant density was 2.4 plants $\cdot \mathrm{m}^{-2}$. Plants were laid out in four double rows, with an in-row spacing of $0.33 \mathrm{~m}$, and a row spacing of $0.80 \mathrm{~m}$. The supply of a standard nutrition solution for cucumber was automatically controlled by a fertigation computer and $\mathrm{pH}$ set point was at 5.6 with small fluctuations
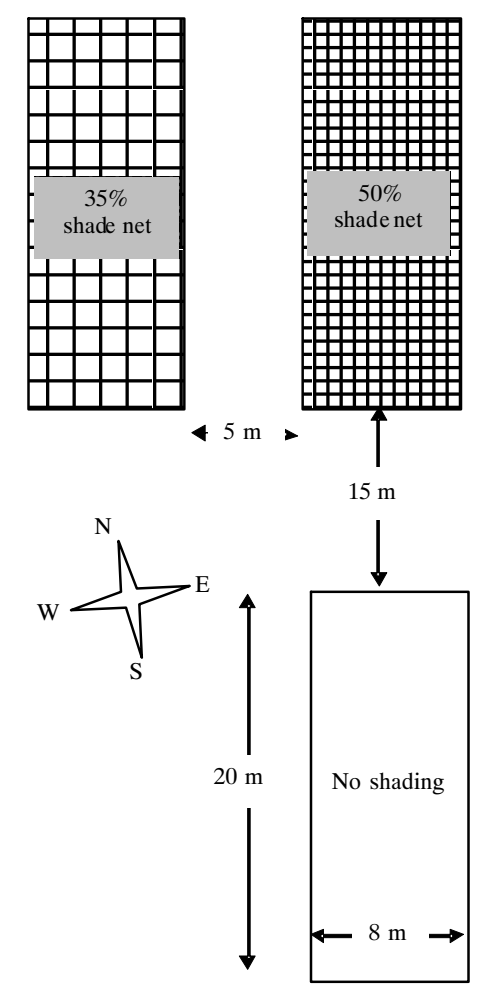

Figure 1. Layout of the experimental greenhouses with indication of the shade nest used for greenhouse shading. 
aimed to maintain the $\mathrm{pH}$ between 5.5 and 6.5 in the drainage solution. The plants were pruned according to the umbrella training system (Klieber et al., 1993) and all other cultural practices not related to the energy balance inside the greenhouse (plant protection, harvesting, etc.) were similar to those practiced commonly by local greenhouse cucumber producers.

Three levels of greenhouse shading were tested, obtained using no net in one of the greenhouses and shade nets made by polypropylene strips (C. Vellis S.A., Piraeus, Greece) differing in hole size. The fixed nets were installed over the external surface of the cover in the two shaded greenhouses. In particular, the three shading treatments were as follows:

- $0 \%$ shading $\left(\mathrm{Gr}_{0 \%}\right)$, greenhouse transmission to solar radiation of approximately $79 \%$,

- $35 \%$ shading $\left(\mathrm{Gr}_{35 \%}\right)$ (net hole size $2 \times 8 \mathrm{~mm}$ ), greenhouse transmission to solar radiation of approximately $50 \%$, and

- $50 \%$ shading $\left(\mathrm{Gr}_{50 \%}\right)$ (net hole size $1 \times 8 \mathrm{~mm}$ ), greenhouse transmission to solar radiation of approximately $38 \%$.

The values of greenhouse transmission to solar radiation are the mean values calculated using the ratio of inside to outside solar radiation during the experimental period.

In the spring-summer crop, the three different shading treatments were commenced 46 days after transplanting (DAT), specifically on 27 May 2008, and maintained up to crop termination. In the autumn crop, shading was installed immediately after transplanting and maintained up to the end of the experiment.

\section{MEASUREMENTS \\ Climate Measurements}

The following climatic data were recorded inside and outside the three experimental greenhouses:

- $\quad$ air temperature $\left(\mathrm{T},{ }^{\circ} \mathrm{C}\right)$ and water vapor pressure $(\mathrm{e}, \mathrm{kPa})$, by means of ventilated psychrometers (wet and dry bulb) (model VP1, Delta-T Devices, Cambridge, England), placed $1.5 \mathrm{~m}$ above the ground (that was $0.5 \mathrm{~m}$ bellow the top of the cucumber plants during spring-summer days presented and at the same level with the top of the crop during autumn days presented) and at the center of each greenhouse and outside $15 \mathrm{~m}$ away from the greenhouse on a mast $3.5 \mathrm{~m}$ above ground;

- solar radiation $\left(\mathrm{W} \mathrm{m}^{-2}\right)$, by means of pyranometers (model Middleton EP08-E, Brunswick Victoria, Australia), placed $2 \mathrm{~m}$ above the ground (that corresponded to a position above plant canopy) at the center of each greenhouse $\left(R_{s, i}\right)$ and outside $\left(R_{s, o}\right) 15$ m away from the greenhouse on a mast $3.5 \mathrm{~m}$ above ground.

- crop transpiration rate $\mathrm{E}_{\mathrm{c}}\left(\mathrm{kg} \mathrm{m}^{-2} \mathrm{~s}^{-1}\right)$ was measured every ten minutes by means of weighing lysimeters, located at a central plant row in two of the three greenhouses, particularly in those with $0 \%$ and $35 \%$ shading. $\mathrm{E}_{\mathrm{c}}$ of the $50 \%$ shading greenhouse was not measured. The device used for crop transpiration measurements included an electronic balance (model 60000 G SCS, capacity of $62 \mathrm{~kg}$, accuracy of $\pm 1 \mathrm{~g}$, Precisa, Zurich, Switzerland) equipped with a tray carrying three plants, and an independent system of water supply and drainage. Considering that perlite was completely covered by bags and thus evaporation losses from the substrate were negligible, the weight loss measured by the electronic balance was assumed to be equal to crop transpiration.
- Additionally, measurements of wind speed $\left(\mathrm{m} \mathrm{s}^{-1}\right)$, with a cup anemometer (model AN1-UM-3, Delta-T Devices, Cambridge, UK) and wind direction, with a wind vane (model WD1-UM-3, Delta-T Devices, Cambridge, UK) were carried out on a mast $4 \mathrm{~m}$ above the ground and $15 \mathrm{~m}$ away from the greenhouse.

Air temperature and relative humidity and solar radiation sensors were calibrated before their use in the experimental period. All of the above-mentioned measurements were recorded in four data logger systems $\left(\mathrm{ZENO}^{\circledR}{ }_{-} 3200\right.$, Coastal Environmental Systems, Inc., Seattle, Wash.). Sensors were scanned every $30 \mathrm{~s}$ and the data was averaged and stored every 10 -min time intervals except for the lysimeter data where the real-time vales were recorded every 10 minutes.

\section{Crop Measurements}

A series of non-destructive measurements was made in 16 randomly selected plants per greenhouse, eight times during the experimental period and plant stem length, leaf number and length $(L)$, and width $(W)$ of each leaf were measured. A scanner (GT 9500, Epson, Nagano, Japan) was used to measure leaf area $(L A)$ in sample plants during the experimental period. These measurements allowed correlating $L A$ to leaf $L$ and $W$ and the correlation was used afterwards to estimate $L A$ as a relationship of $L$ and $W$ measurement in each plant. Fruits were harvested twice a week, starting on 20 May and finishing on 10 July. The harvested fruits from the abovementioned 16 randomly selected plants were weighted and the total production per greenhouse $\mathrm{m}^{2}$ was calculated. The statistical package SPSS (SPSS-14.0 for Windows standard version, 2005, SPSS BI Greece S.A.) was used for statistical analysis of the data. Data were analyzed using ANOVA $(\mathrm{P} \leq 0.05)$ and Duncan's multirange post hoc tests.

\section{Calculations \\ Greenhouse Energy Balance}

The energy balance in the greenhouse, according to the ASAE Standards (2003) can be written in the following simplified form:

$$
(1-\varepsilon) R_{s}, i=U\left(T i-T_{o}\right)+\rho C_{p} Q\left(T e-T_{o}\right)
$$

where $\varepsilon$ is the 'evaporation' coefficient, which represents the ratio of the latent energy released by the canopy and the floor to the heat load. The latter is usually taken equal to the inside global radiation $R_{\mathrm{s}, \mathrm{i}}$ because the net radiation, which is a better estimate of the actual heat load, is not frequently available. The heat transfer coefficient through the cover is depicted by $U$ in $\mathrm{W} \mathrm{m} \mathrm{m}^{-2} \mathrm{~K}^{-1}$, and $T_{\mathrm{e}}$ is the exhaust air temperature considered equal to greenhouse air temperature $T_{\mathrm{i}}$ (Seginer, 1997). In order to calculate $\varepsilon$, equation 1 and $U=$ $6.2 \mathrm{~W} \mathrm{~m}^{-2}{ }^{\circ} \mathrm{C}^{-1}$ (ASAE Standards, 2003) were used.

$Q$ is the greenhouse ventilation rate as calculated using the simplified relationship suggested by Kittas et al. (1996):

$$
Q=\frac{A_{T}}{2} C_{d} \sqrt{C_{w}} \text { uo }+Q 0
$$

where $u_{\mathrm{o}}$ is the outside air speed, $A_{\mathrm{T}}\left(\mathrm{m}^{2}\right)$ the actual vent opening area, $Q_{0}\left(\mathrm{~m}^{3} \mathrm{~s}^{-1}\right)$ the leakage ventilation, and $C_{\mathrm{d}}$ $C_{\mathrm{w}} 0.5$ the wind and vent related coefficient, where $C_{\mathrm{d}}$ is the discharge coefficient and $C_{\mathrm{w}}$ is the overall wind effect 
coefficient (Roy et al., 2002). The parameters $Q_{0}$ and $C_{\mathrm{d}}$ $C_{\mathrm{W}}{ }^{0.5}$ were determined by Katsoulas et al. (2006) for the same experimental greenhouses; and found equal to $0.135 \pm$ $0.149 \mathrm{~m}^{3} \mathrm{~s}^{-1}$ and $0.078 \pm 0.0057$, respectively.

The evaporation from the soil and the substrate were considered negligible, and thus the evaporation coefficient can be also calculated as:

$$
\varepsilon=\lambda \mathrm{E}_{\mathrm{c}} / \mathrm{R}_{\mathrm{s}, \mathrm{i}}
$$

where $\lambda$ is the latent heat of vaporization $\left(\mathrm{J} \mathrm{kg}^{-1}\right)$.

\section{ReSUlTS}

The data selected for analysis are for three consecutive days $(15,16$, and 17 May) before shade nets application and three consecutive days after shade nets application $(1,2$, and 3 June) during the spring experiment, which differed slightly in the outside radiation and temperature conditions, and one representative day during the autumn experimental period, particularly 19 September 2008. The selected days before shading are presented in order to show that the greenhouse microclimate before shading was similar in all three greenhouses and, accordingly, any changes in greenhouse microclimate were due to the different shading treatments. The installation of shade nets during the spring experiment was made on the $46^{\text {th }}$ day after transplanting, namely on 27 May 2008. Thus, on 1, 2, and 3 June, the crop was only a few days under shading and, therefore, no differences in crop development were anticipated. Furthermore, during 19 September, plants had been grown for only 19 days in the greenhouse and, consequently, their leaf area index was relatively low. Accordingly, it is reasonable to attribute any differences in greenhouse microclimate during the selected days to greenhouse shading only and not to differences in crop development between the three greenhouses. The daily mean values (averaged over 09:00 h-18:00 h local time) of the outside climate variables for the days selected are given in table 1 . The $1^{\text {st }}$ of June 2008 was a sunny summer day while 2 and 3 June were relatively cloudy days. The presentation of data for days differing in cloudiness is intentional, aiming to allow for greenhouse microclimate comparisons under different outside radiation conditions.

\section{Greenhouse Microclimate Effect on Radiation}

The diurnal variation of solar radiation inside the three greenhouses and outside, during the selected days before or after shading, is shown in figure 2 .

It can bee seen that before shading, all three greenhouses had similar levels of incoming solar radiation. After shade net application, the solar radiation intensity at mid-day reached very high levels $\left(720 \mathrm{~W} \mathrm{~m}^{-2}\right)$ in the greenhouse without shading, but did not exceed $450 \mathrm{~W} \mathrm{~m}^{-2}$ in the shaded greenhouses. In the spring experiment, the daily averages (09:00 - 18:00) of the incoming solar radiation intensity during the three selected days were $455( \pm 198) \mathrm{W} \mathrm{m}^{-2}, 290$ $( \pm 128) \mathrm{W} \mathrm{m}^{-2}$, and $220( \pm 107) \mathrm{W} \mathrm{m}^{-2}$ in the greenhouses corresponding to $\mathrm{Gr}_{0 \%}, \mathrm{Gr}_{35 \%}$, and $\mathrm{Gr}_{50 \%}$, respectively. During the same days, the daily average of the outside solar radiation intensity was $562( \pm 226) \mathrm{W} \mathrm{m}^{-2}$. The values in parenthesis represent standard deviation of mean. The maximum values of solar radiation observed in $\mathrm{Gr}_{0 \%}, \mathrm{Gr}_{35 \%}$,
Table 1. Average (and standard deviation in parenthesis) and maximum values of climatic variables outside the greenhouse over the period 09:00 h-18:00 h local time during seven selected days.

\begin{tabular}{lccccc}
\hline & $\begin{array}{c}R_{\mathrm{s}, \mathrm{o}}{ }^{[\mathrm{a}]} \\
\left(\mathrm{MJ} \mathrm{m}^{-2}\right)\end{array}$ & $\begin{array}{c}T_{\mathrm{o}}{ }^{\mathrm{b}]} \\
\left({ }^{\circ} \mathrm{C}\right)\end{array}$ & $\begin{array}{c}R H_{o}{ }^{[\mathrm{c}]} \\
(\%)\end{array}$ & $\begin{array}{c}V P D_{\mathrm{o}}{ }^{[\mathrm{d}]} \\
(\mathrm{kPa})\end{array}$ & $\begin{array}{c}u_{o}{ }^{[\mathrm{e}]} \\
\left(\mathrm{m} \mathrm{s}^{-1}\right)\end{array}$ \\
\hline 15 May & 20.7 & $21.7( \pm 2.9)$ & $41.4( \pm 11.9)$ & $1.59( \pm 0.52)$ & $2.1( \pm 0.6)$ \\
16 May & 20.5 & $23.4( \pm 3.1)$ & $37.5( \pm 5.4)$ & $1.85( \pm 0.45)$ & $2.0( \pm 0.9)$ \\
17 May & 20.4 & $24.5( \pm 3.2)$ & $37.6( \pm 6.7)$ & $1.98( \pm 0.50)$ & $2.3( \pm 1.2)$ \\
1 June & 21.8 & $27.3( \pm 2.9)$ & $37.3( \pm 8.3)$ & $2.35( \pm 0.63)$ & $2.0( \pm 0.7)$ \\
2 June & 19.4 & $25.7( \pm 1.1)$ & $45.3( \pm 5.1)$ & $1.82( \pm 0.28)$ & $4.3( \pm 1.1)$ \\
3 June & 16.5 & $22.0( \pm 1.1)$ & $47.4( \pm 4.7)$ & $1.4( \pm 0.21)$ & $3.6( \pm 1.1)$ \\
19 Sept & 14.3 & $18.6( \pm 2.1)$ & $44.0( \pm 6.0)$ & $1.23( \pm 0.27)$ & $1.9( \pm 0.5)$ \\
\hline
\end{tabular}

[a] $R_{S, o}=$ global radiation $\left(\mathrm{MJ} \mathrm{m}^{-2}\right)$.

[b] $T_{o}=$ air temperature $\left({ }^{\circ} \mathrm{C}\right)$.

[c] $R H_{O}=$ air relative humidity $(\%, \mathrm{kPa})$.

[d] $V P D_{o}=$ vapor pressure deficit $(\mathrm{kPa})$.

[e] $u_{o}=$ wind speed $\left(\mathrm{m} \mathrm{s}^{-1}\right)$.

and $\mathrm{Gr}_{50 \%}$, during the $1^{\text {st }}$ of June were $730 \mathrm{~W} \mathrm{~m}^{-2}, 445 \mathrm{~W} \mathrm{~m}^{-2}$, and $365 \mathrm{~W} \mathrm{~m}^{-2}$, respectively. The respective mean values during 19 September were $353( \pm 160) \mathrm{W} \mathrm{m}^{-2}, 210( \pm 110)$ $\mathrm{W} \mathrm{m}{ }^{-2}$, and $160( \pm 90) \mathrm{W} \mathrm{m}^{-2}$ in the $\mathrm{Gr}_{0 \%}, \mathrm{Gr}_{35 \%}$, and $\mathrm{Gr}_{50 \%}$, respectively, while the mean value of the outside solar radiation during the same day was $420( \pm 200) \mathrm{W} \mathrm{m}^{-2}$.

The greenhouse radiation transmission coefficient, $\tau$, was calculated from the ratio of inside to outside solar irradiance $\left(\tau=R_{\mathrm{S}, \mathrm{i}} / R_{\mathrm{S}, \mathrm{o}}\right)$. The diurnal variation of $\tau$ during the selected days is shown in figure 3 .

The average values of $\tau$ in the three greenhouses during the period between 09:00-18:00 were about 0.78 \pm 0.07 before shading, and $0.79 \pm 0.06,0.50 \pm 0.07$, and $0.38 \pm 0.05$, for $\mathrm{Gr}_{0 \%}, \mathrm{Gr}_{35 \%}$, and $\mathrm{Gr}_{50 \%}$, respectively, during the selected days after shading application. The observed fluctuations around the mean values were due to the interception of direct solar irradiance by the greenhouse structure and internal equipment located above the radiation sensors and the change of solar incidence angle (Wang and Boulard, 2000). The maximum transmission coefficients observed by noon during the selected days were $0.91,0.64$, and 0.49 for the $\mathrm{Gr}_{0 \%}, \mathrm{Gr}_{35 \%}$, and $\mathrm{Gr}_{50 \%}$, respectively, when no internal obstacle was interfering.

\section{Effect on Temperature and Air Vapor Pressure Deficit}

The diurnal variation of the air temperature in the three greenhouses before shading (fig. 4a) shows that the air temperature was similar in the three greenhouses before shading. The diurnal variation of air temperature during the selected days of June (fig. 4b) indicates that shading reduced greenhouse air temperature. Similar reduction was observed for the air vapor pressure deficit (data not shown).

The diurnal variation of air temperature difference between $\mathrm{Gr}_{0 \%}$ and $\mathrm{Gr}_{50 \%}$ and between $\mathrm{Gr}_{0 \%}$ and $\mathrm{Gr}_{35 \%}$ (fig. 5), shows that $\mathrm{Gr}_{50 \%}$ and $\mathrm{Gr}_{35 \%}$ had clearly lower temperature conditions than those observed in $\mathrm{Gr}_{0 \%}$. Similar trend, as obtained with air temperature, was observed for the air vapor pressure deficit differences between the non shaded and shaded greenhouses with no significant differences between the two shaded greenhouses (data not shown).

The mean values (average 09:00 $\mathrm{h}-18: 00 \mathrm{~h}$ ) of air temperature and air vapor pressure deficit (VPD) during the selected days before and after shading are presented in table 2. During the clear sunny day (1 June), the mean 


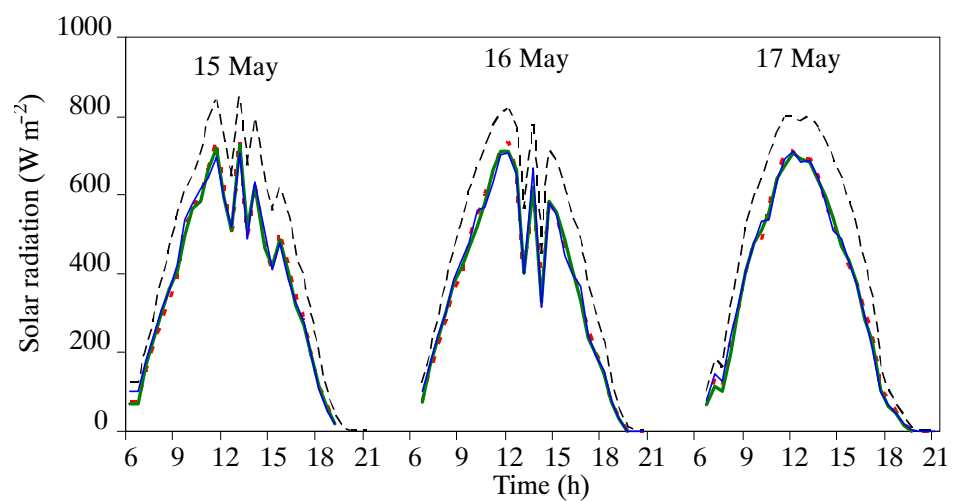

(a)

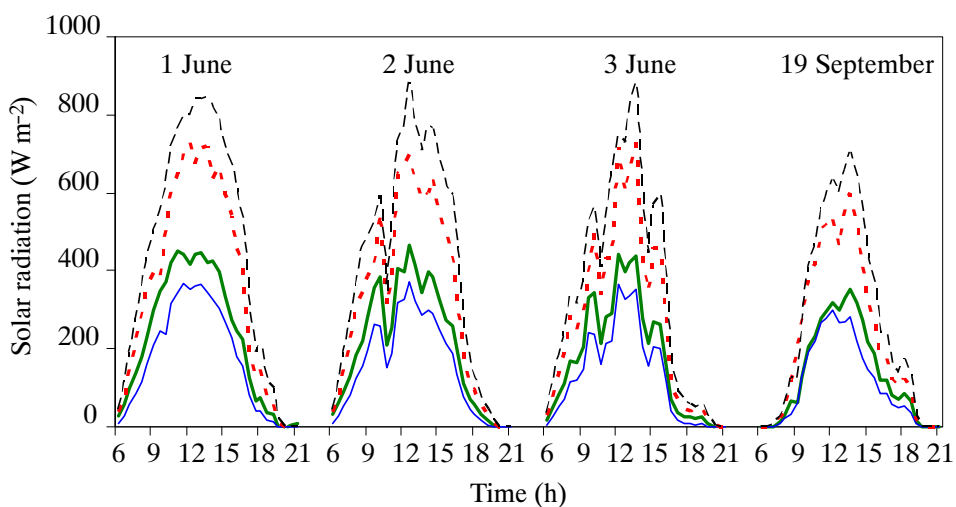

(b)

Figure 2. Daily course of solar radiation during (a) three selected days without shading and (b) four selected days with shading. Discontinuous thick line: outside; discontinuous thin line: $\mathbf{G r}_{0} \%$; continuous thick line: $\mathbf{G r}_{35 \%}$; continuous thin line: $\mathbf{G r}_{50 \%}$.

greenhouse air temperature reduction due to shading was about $1.8^{\circ} \mathrm{C}$ in the greenhouse with moderate shading and $3.9^{\circ} \mathrm{C}$ in the greenhouse with high shading. The maximum air temperature values observed during the clear sunny day in $\mathrm{Gr} 0 \%, \mathrm{Gr} 35 \%$ and $\mathrm{Gr} 50 \%$ were $41.7 .8^{\circ} \mathrm{C}, 38.8^{\circ} \mathrm{C}$, and $36.8^{\circ} \mathrm{C}$, respectively, which clearly indicate the beneficial effect of shading on greenhouse air temperature conditions.

On daily average, compared to the 1 June, VPD values were reduced by $30 \%$ on the two cloudy days ( 2 and 3 June), while they were even more strongly reduced during the autumn experimental period. The maximum air VPD values that were observed during the sunny day (1 June) in $\mathrm{Gr}_{0 \%}$, $\mathrm{Gr}_{35 \%}$, and $\mathrm{Gr}_{50 \%}$ were 6.0 , 4.6, and $4.3 \mathrm{kPa}$, respectively.

\section{Effect of Shading on Crop Transpiration Rate}

Figure 6 presents the diurnal variation of crop transpiration rate in two of the three greenhouses $\left(\mathrm{Gr}_{0 \%}\right.$ and $\mathrm{Gr}_{35 \%}$ ) during the selected days.

The major differences were observed during the period between 10:00 and 17:00. The mean daily values of $\lambda E_{\mathrm{c}}$ observed in $\mathrm{Gr}_{0 \%}$ and $\mathrm{Gr}_{35 \%}$ were $65( \pm 18) \mathrm{W} \mathrm{m}^{-2}$ and 48 $( \pm 18) \mathrm{W} \mathrm{m}^{-2}$, and $44( \pm 16) \mathrm{W} \mathrm{m}^{-2}$ and $35( \pm 11) \mathrm{W} \mathrm{m}^{-2}$, during the selected days in spring and autumn, respectively. The average decrease of crop transpiration rate due to shading over the 4-day period was $24 \%$; the higher decrease $(38 \%)$ was observed during the sunny day (1 June), whereas

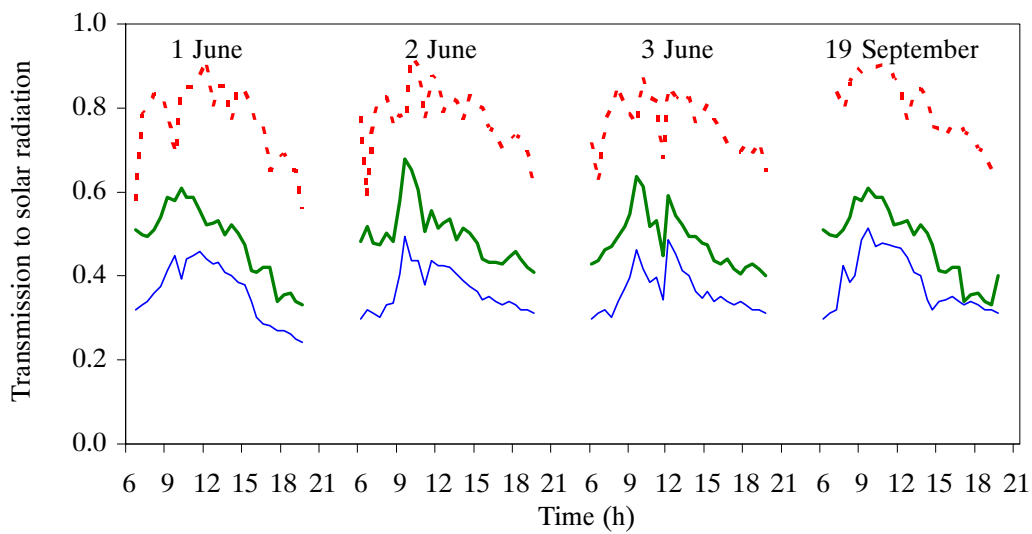

Figure 3. Daily course of greenhouse solar radiation transmission during the four selected days. Discontinuous line: Gro\%; continuous thick line: $\mathbf{G r}_{35 \%}$; continuous thin line: $\mathbf{G r}_{50 \%}$. 


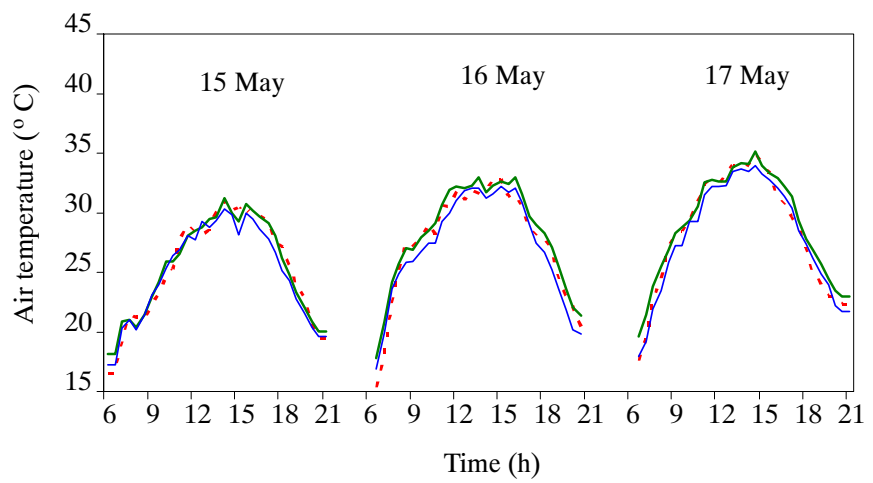

(a)

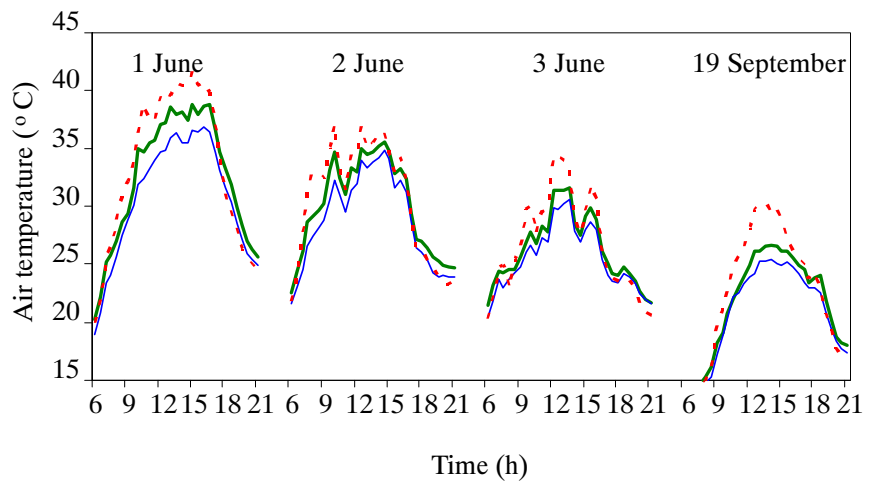

(b)

Figure 4. Diurnal variation of air temperature in the three greenhouses during (a) three selected days without shading, and (b) four selected days with shading. Discontinuous line: $\mathbf{G r}$ \% ; continuous thick line: $\mathbf{G r}_{35 \%}$; continuous thin line: $\mathbf{G r}_{50 \%}$.

the lowest decrease (15\% and 18\%) occurred during the cloudy days ( 2 and 3 June, respectively).

\section{Greenhouse Energy Balance}

The values of $\varepsilon$ calculated by applying the greenhouse energy balance method (eq. 1) did not differ significantly between the three greenhouses. The average values of $\varepsilon$ in $\mathrm{Gr}_{0 \%}, \mathrm{Gr}_{35 \%}$ and $\mathrm{Gr}_{50 \%}$ during the three selected days were $0.32( \pm 0.20), 0.28( \pm 0.18)$, and $0.30( \pm 0.12)$, respectively. The mean values of $\varepsilon$ during the sunny day (1 June) were about $50 \%$ higher than those observed during the two cloudy days ( 2 and 3 June). The average values of $\varepsilon$ observed in $\mathrm{Gr}_{0 \%}, \mathrm{Gr}_{35 \%}$, and $\mathrm{Gr}_{50 \%}$ on 19 September were 0.39 ( \pm 0.20$)$, $0.38( \pm 0.08)$, and $0.42( \pm 0.11)$, respectively. The average values of $\varepsilon$ that were calculated for the three selected days using equation 2 were $0.26( \pm 0.08)$ and $0.27( \pm 0.05)$, for $\mathrm{Gr}_{0 \%}$ and $\mathrm{Gr}_{35 \%}$, respectively. These values of $\varepsilon$ were lower than those observed using equation 1 with the maximum difference being about $19 \%$.

\section{Crop Production}

Measurements of leaf length $(L, \mathrm{~cm})$, width $(W, \mathrm{~cm})$, and area $\left(L A, \mathrm{~cm}^{2}\right)$ on randomly selected plants during the period of measurements were used for the development and calibration of a formula for $L A$ calculation as a function of leaf $L$ and $W$ characteristics. A good correlation was obtained between the $L A$ and $L$ and between $L A$ and the product $L \times$ $W$. The relations obtained were:

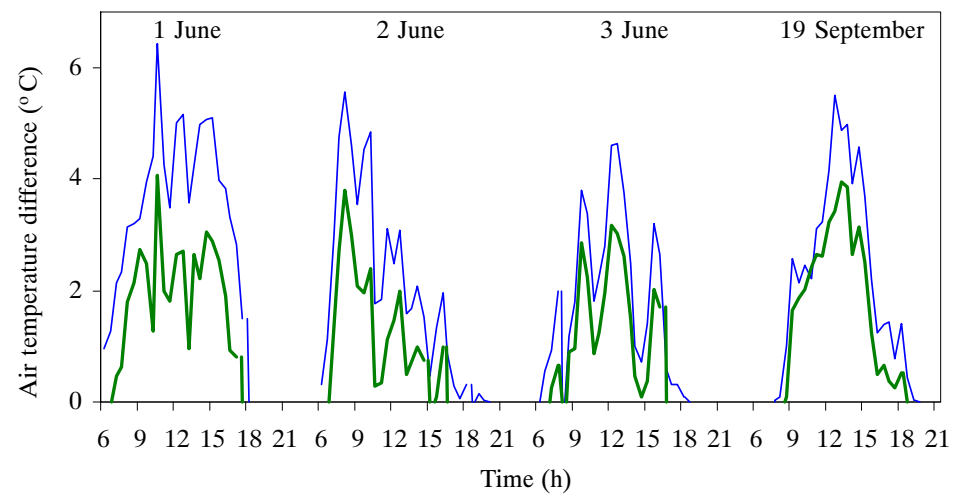

Figure 5. Diurnal variation of air temperature difference between the greenhouse with no shading and the greenhouses with $35 \%$ and $50 \%$ shading

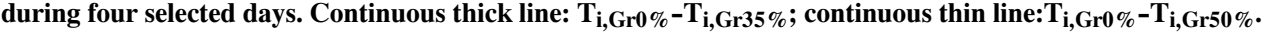


Table 2. Average values (and standard deviation in parenthesis) of greenhouse air temperature $T i$ and vapor pressure deficit $V P D_{i}$ over the period 09:00 h-18:00 h local time during seven selected days in three greenhouses differing in shading level.

\begin{tabular}{|c|c|c|c|c|c|c|}
\hline \multirow[b]{2}{*}{ Day } & \multicolumn{3}{|c|}{$\operatorname{Ti}\left({ }^{\circ} \mathrm{C}\right)^{[\mathrm{a}]}$} & \multicolumn{3}{|c|}{$V P D_{i}(\mathrm{kPa})$} \\
\hline & $\mathrm{Gr}_{0 \%}$ & $\mathrm{Gr}_{35 \%}$ & $\mathrm{Gr}_{50 \%}$ & $\mathrm{Gr}_{0 \%}$ & $\mathrm{Gr}_{35 \%}$ & $\mathrm{Gr}_{50 \%}$ \\
\hline 15 May & $28.0( \pm 2.5)$ & $28.1( \pm 2.2)$ & $27.6( \pm 2.1)$ & $2.7( \pm 0.5)$ & $2.8( \pm 0.7)$ & $2.6( \pm 0.5)$ \\
\hline 16 May & $30.2( \pm 1.9)$ & $30.8( \pm 2.0)$ & $29.8( \pm 2.2)$ & $2.9( \pm 0.4)$ & $3.0( \pm 0.5)$ & $2.8( \pm 0.4)$ \\
\hline 17 May & $31.5( \pm 2.4)$ & $31.9( \pm 2.2)$ & $31.1( \pm 2.3)$ & $3.2( \pm 0.9)$ & $3.3( \pm 0.9)$ & $3.0( \pm 0.8)$ \\
\hline 1 June & $38.0( \pm 3.1)$ & $36.2( \pm 2.6)$ & $34.1( \pm 2.3)$ & $4.6( \pm 1.0)$ & $3.6( \pm 1.0)$ & $3.4( \pm 0.9)$ \\
\hline 2 June & $33.3( \pm 3.2)$ & $32.3( \pm 2.5)$ & $30.8( \pm 2.4)$ & $3.2( \pm 0.6)$ & $2.8( \pm 0.5)$ & $2.7( \pm 0.6)$ \\
\hline 3 June & $29.2( \pm 3.4)$ & $28.0( \pm 2.4)$ & $27.0( \pm 2.2)$ & $2.4( \pm 0.7)$ & $2.1( \pm 0.6)$ & $2.0( \pm 0.5)$ \\
\hline 19 September & $26.2( \pm 3.1)$ & $24.1( \pm 2.5)$ & $23.6( \pm 2.3)$ & $1.7( \pm 0.4)$ & $1.8( \pm 0.4)$ & $1.5( \pm 0.3)$ \\
\hline
\end{tabular}

[a] $\mathrm{Gr}_{0 \%} ; 0 \%$ shading, greenhouse transmission to solar radiation of about $79 \%$;

$\mathrm{Gr}_{35 \%}$ : $35 \%$ shading, greenhouse transmission to solar radiation of about $50 \%$;

$\mathrm{Gr}_{50 \%}: 50 \%$ shading, greenhouse transmission to solar radiation of about $38 \%$.

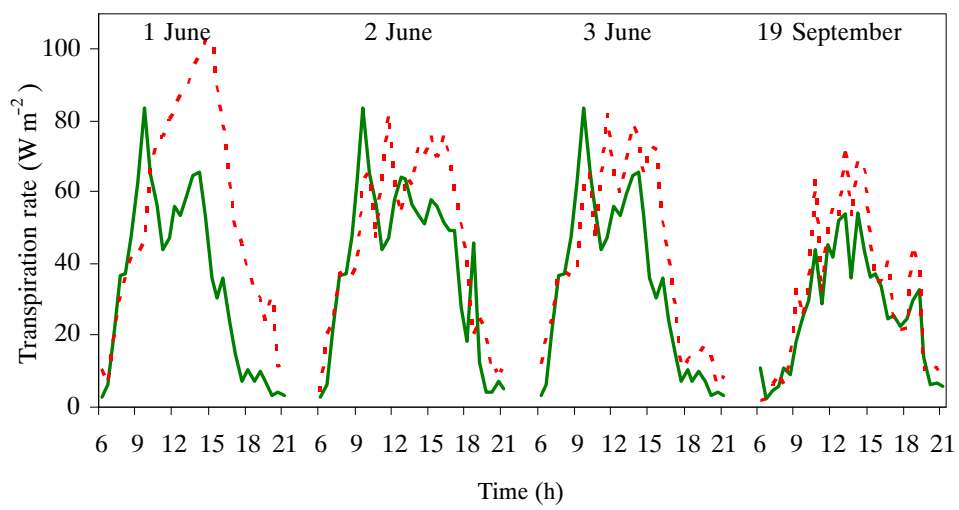

Figure 6. Diurnal variation of crop transpiration in the non-shaded greenhouse and in the $35 \%$ shaded greenhouse during the four selected days. Discontinuous line: $\mathbf{G r}_{0} \%$; continuous line: $\mathbf{G r}_{35 \%}$.

$$
\begin{gathered}
\mathrm{LA}=26 \mathrm{~L}-182 \\
\mathrm{LA}=0.77 \mathrm{~L} \mathrm{~W}+6.5
\end{gathered}
$$

with $\mathrm{R}^{2}$ values of 0.94 and 0.95 , respectively. When equations $4 \mathrm{a}$ and $4 \mathrm{~b}$ calibrated using the data of each greenhouse separately, no significant differences were found between their constant parameters for the different greenhouses. The leaf area index values found in $\mathrm{Gr}_{35 \%}$ and $\mathrm{Gr}_{50 \%}$ where significantly higher than those observed in $\mathrm{Gr}_{0 \%}$ after 15 June but no statistical differences were found in the number of leaves-nodes of cucumber plants between the three treatments (data not shown). The crop leaf area index $I_{\text {LA }}\left[\mathrm{m}^{2}\right.$ (leaf) $\mathrm{m}^{-2}$ (ground)] was about 1.5 during the fist days of June and about 0.7 during the 19 of September.

It was found that shading increased the number of harvested fruit and the total crop production (fig. 7). It can be seen that the values of cumulative fruit weight and number were higher for the $\mathrm{Gr}_{35 \%}$ than for the $\mathrm{Gr}_{0 \%}$ and $\mathrm{Gr}_{50 \%}$. The values of fruit production and fruit number observed at the end of experimental period were $9.8 \mathrm{~kg} \mathrm{~m}^{-2}, 15.1 \mathrm{~kg} \mathrm{~m}^{-2}$, and $11.2 \mathrm{~kg} \mathrm{~m}^{-2}$ and 25.6 fruit $\mathrm{m}^{-2}, 39.4$ fruit $\mathrm{m}^{-2}$, and 29.4 fruit $\mathrm{m}^{-2}$ for $\mathrm{Gr}_{0 \%}, \mathrm{Gr}_{35 \%}$, and $\mathrm{Gr}_{50 \%}$, respectively. The mean value of fruit weight was about $0.38 \mathrm{~kg}^{\text {fruit }}{ }^{-1}$ for all three greenhouses.

\section{Discussion \\ Changes in Microclimate}

When nets were applied in the two greenhouses, the incoming solar radiation was reduced by about $35 \%$ and $50 \%$ (figs. 2 and 3). This reduction of incoming solar radiation lead to greenhouse air temperature and vapor pressure deficit modifications. The high values of air temperature and vapor pressure deficit observed during the sunny day under no shading conditions [air temperature $\approx 41^{\circ} \mathrm{C}$ (fig. $4 \mathrm{~b}$ ) and vapor pressure deficit $\approx 6 \mathrm{kPa}$ ] were reduced under shading, the maximum air temperature and vapor pressure deficit values observed during the same day under shading were $38^{\circ} \mathrm{C}$ and $36^{\circ} \mathrm{C}$ and 4.5 and $4.3 \mathrm{kPa}$ for the $\mathrm{Gr}_{35 \%}$ and $\mathrm{Gr}_{50 \%}$ treatments, respectively. However, shading was incapable of maintaining the greenhouse air temperature and humidity to optimal levels $\left(25^{\circ} \mathrm{C}\right.$ and $70 \%$, respectively, Bulder et al., 1987), or at least at temperature levels below $30^{\circ} \mathrm{C}$ (Growers Books, 1980; Olympios and Hanan, 1992) and $V P D_{\text {i below }}$ $1.5 \mathrm{kPa}$ (Bakker et al., 1987).

The difference between the values of incoming solar radiation observed in the control greenhouse $\left(\mathrm{Gr}_{0 \%}\right)$ and the greenhouse with the highest shading intensity $\left(\mathrm{Gr}_{50 \%}\right)$ was 270,220 , and $200 \mathrm{~W} \mathrm{~m}^{-2}$ on the sunny (1 June) and cloudy days (2 and 3 June), respectively, and the measured differences in air temperature between $\mathrm{Gr}_{0 \%}$ and $\mathrm{Gr}_{50 \%}$ during the sunny ( 1 June) and cloudy ( 2 and 3 June) days were $3.9^{\circ} \mathrm{C}, 2.5^{\circ} \mathrm{C}$, and $2.2^{\circ} \mathrm{C}$, respectively. Willits (2001) note that when screens are used, the solar radiation decrease does not always involve a notable temperature decrease, 

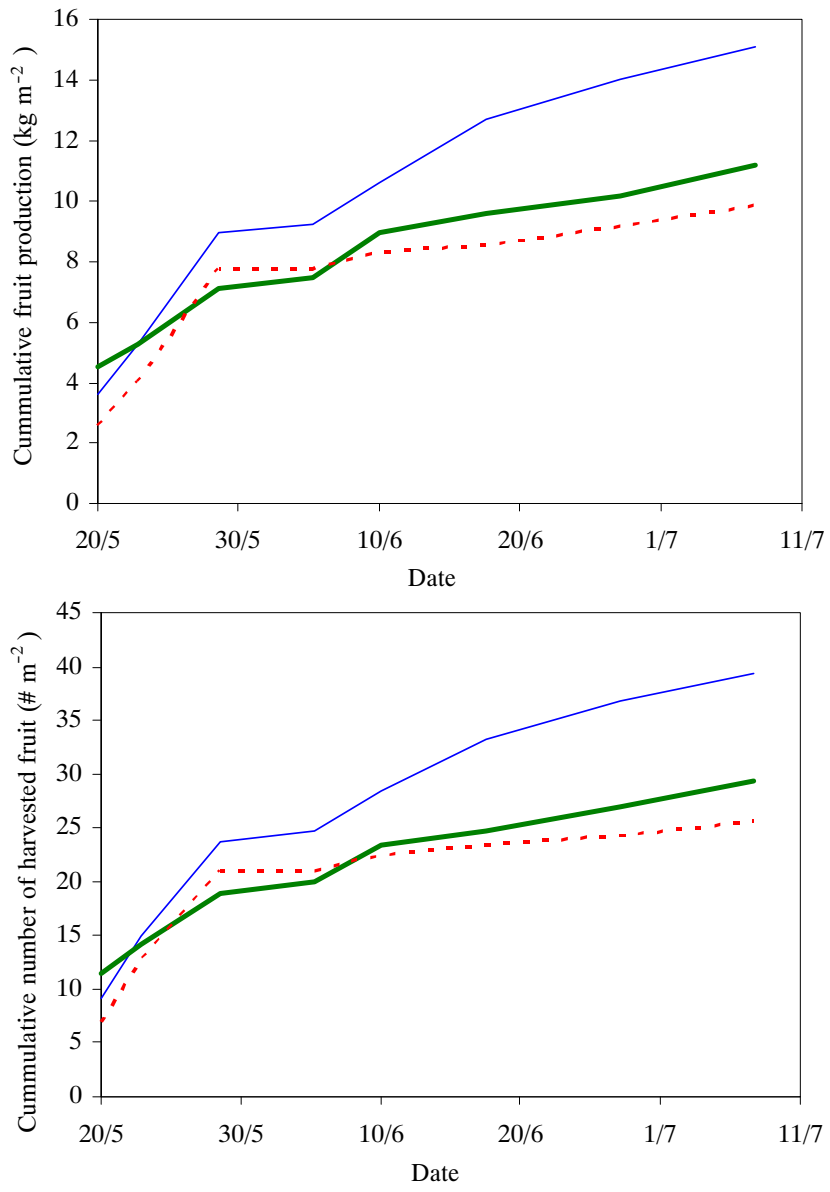

Figure 7. Development of (a) cumulative harvested fruit production and (b) cumulative harvested fruit number per $\mathrm{m}^{-2}$ of greenhouse ground area. Discontinuous line: $\mathbf{G r}_{0 \%}$; continuous thick line: $\mathbf{G r}_{35 \%}$; continuous thin line: $\mathbf{G r}_{50 \%}$.

especially when the ventilation rates are low. A high radiation absorption by the screen can contribute to an increase in the amount of energy transferred by convection into the greenhouse.

To quantify the effect of shading intensity on greenhouse air temperature, a linear regression analysis was carried out between the air temperature measured inside the three greenhouses $T_{\mathrm{i}}$ and the outside air temperature $T_{\mathrm{O}}$ and solar radiation $R_{\mathrm{S}, \mathrm{o}}$ in order to calibrate the following equation:

$$
\mathrm{T}_{\mathrm{i}}=\mathrm{a} \mathrm{T}_{\mathrm{o}}+\mathrm{b} \tau \mathrm{R}_{\mathrm{s}, \mathrm{o}}+\mathrm{c}
$$

The coefficients $a, b$, and $c$, as calculated by replacing the values of $T_{o}, \tau$, and $R_{s, o}$ that were measured on 1,2 , and 3 June in equation 5 amounted to 1.013 (with a standard error of \pm 0.040 ), 0.014 (with a standard error of \pm 0.001 ), and 2.370 (with a standard error of \pm 1.010 ), respectively, with a correlation coefficient $\mathrm{R}^{2}$ of 0.88 . Consequently, the calibrated equation 5 explains an $88 \%$ of the variability of $T_{i}$. Moreover, the small standard errors of $\mathrm{a}, \mathrm{b}$ and $\mathrm{c}$ indicate that the results of the calibration are satisfactory. Equation 5 shows that greenhouse air temperature increase of about $1^{\circ} \mathrm{C}$ for every $100 \mathrm{~W} \mathrm{~m}^{-2}$ of increase of incoming solar radiation. Similar results were found by Kittas et al. (1987) for a plastic tunnel in the South of France.

Using equation 5 , it is easy to calculate the difference between the inside and outside air temperature as a function of solar radiation and the level of greenhouse shading. Although equation 5 and the standard ASABE ventilation formula (eq. 1) both refer to the greenhouse air temperature, the proper temperature criterion is canopy temperature $T_{\mathrm{c}}$ (Seginer, 2002). Hence, it would be interesting to estimate the effect of shading on canopy to greenhouse air temperature difference than on greenhouse to outside air temperature difference. On this purpose, the following simple model for crop temperature estimation was used (Boulard and Baille, 1993):

$$
T c-T i=\frac{\zeta R_{s, i}-\lambda E_{c}}{g_{a} \rho C_{p} I L A}
$$

where $\zeta$ is the canopy absorption coefficient for solar radiation, $\mathrm{g}_{\mathrm{a}}\left(\mathrm{m} \mathrm{s}^{-1}\right)$ is the crop aerodynamic conductance, and $\rho\left(\mathrm{kg} \mathrm{m}^{-3}\right)$ and $C_{\mathrm{p}}\left(\mathrm{j} \mathrm{kg}^{-1}{ }^{\circ} \mathrm{C}^{-1}\right)$ the air density and specific heat of air, respectively. The crop aerodynamic conductance can be calculated using the equation suggested by Monteith (1973):

$$
g_{a}=2 I_{L A} 6.62 * 10^{-3}\left(\frac{u i}{d}\right)^{0.5}
$$

where $u_{\mathrm{i}}\left(\mathrm{m} \mathrm{s}^{-1}\right)$ is the mean air velocity inside the greenhouse and $d(\mathrm{~m})$ is the characteristic leaf length of cucumber crop [usually taken as 0.7 times the maximum leaf dimension in the direction of air flow (Campbell, 1986)]. The $d$ value used was equal to $0.35 \mathrm{~m}$, as calculated using leaf length measurements taken during both experimental periods.

Mean greenhouse air velocity can be calculated using the equation:

$$
u i=\frac{Q}{A v}
$$

where $A_{\mathrm{v}}$ is the area of a vertical cross-section of the greenhouse. Using equation 7 , the mean value of $g_{\mathrm{a}}$ calculated was $60 \mathrm{~m} \mathrm{~s}^{-1}$.

Taking into account the above considerations, a $\xi$ value equal to 0.82 (Heuvelink, 1996; Rosati et al., 2001) and that $\lambda E_{\mathrm{c}}$ is equal to $0.42 R_{\mathrm{s}, \mathrm{i}}$ (Yang et al., 1990), the crop to greenhouse air temperature difference was calculated (fig. 8).

As shown in figure 8 , a greenhouse transmission coefficient of 0.4 could result in crop temperature values lower than the air temperature values while lower shading intensity ( $\tau=0.6$ or 0.8 ) results in crop temperature values higher than the air temperature. In that case, other means for greenhouse cooling along with shading are necessary such as fogging combined by natural ventilation (Katsoulas et al., 2007; 2009).

\section{Crop Response}

The canopy transpiration rate (fig. 6) was affected to a lesser extent than the solar radiation intensity by shading. During the summer period, the difference in $\lambda E_{\mathrm{c}}$ between the non-shaded greenhouse and that shaded by $35 \%$ was approximately $25 \%$ when integrated over the whole diurnal period, which is considered moderate. The same type of feedback was reported when a mist system was used for cooling, which decreased the vapor pressure deficit in the greenhouse air (Baille et al., 2001). 


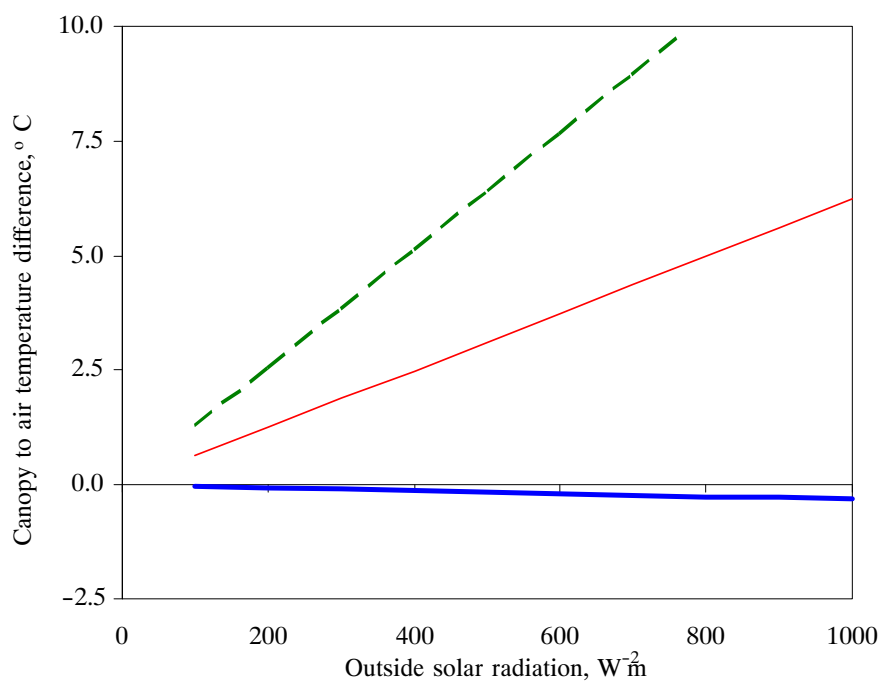

Figure 8. Canopy to air temperature difference as a function of outside solar radiation for several values of greenhouse transmission coefficient $\tau$ calculated using eq. 10. Continuous thick line: $\tau=0.4$; continuous thin line: $\tau=0.6$; discontinuous line: $\tau=0.8$.

The higher leaf area index and crop production observed under $35 \%$ shading compared to no shading conditions could probably be due to better water status and higher photosynthetic rates of plants under shading. Reducing crop temperature and vapor pressure deficit could greatly affect plant growth through different processes: (a) by improving the leaf water status (Stirzaker et al., 1997) which increases leaf conductance and hence $\mathrm{CO}_{2}$-assimilation (Bakker, 1990) and (b) by decreasing fruit transpiration (Leonardi et al., 2000). Ogren and Evans (1992) mention that exposure of leaves to excessive light causes photoinhibition that is associated with photosynthesis decrease. The above, along with the fact that diffuse fraction of solar radiation is higher under shading (Abdel-Ghany and Al-Helal, 2010), favoring radiation penetration in the lower parts of the canopy and increasing canopy interception, could explain the increase in crop production observed under $35 \%$ shading compared to no shading conditions. Similar results were also found by other authors for tomato crop (El-Gizawy et al., 1993; Naraghi and Lotfi, 2010). Crop production under shading higher than 35\% was not improved. The higher production was accompanied by a higher number of fruits. Since no statistical significant differences in number of nodes-flowers between the greenhouses were detected, the higher yield under 35\% shade could be attributed to flower and fruit abortion of unshaded plants, which was also observed by El-Gizawy et al. (1993) and Naraghi and Lotfi (2010). Abortion of flowers and fruit depends on the source/sink ratio of carbon in the plant (Marcelis et al., 2004). Kitao et al. (2000) noted that excessive light intensity affects plant growth by promoting photo oxidation of chloroplast components which provoke reduction of productivity as a result of photo inhibition. The number of flowers and fruit creates a demand for plant resources, and if the plant cannot meet the demand due to decreased photosynthetic rates, resulting from exposure of unshaded plants to high or low light levels, high rates of abortion of newly formed fruit can occur (Bakker 1989). It appears that a physiologically-based optimal value of shading intensity exists, and that this value depends on several factors: the outside climate conditions (solar radiation, air temperature, and humidity), the greenhouse characteristics (ventilation rate, radiation transmission coefficient, cooling system), which affect the thermal and hydrological negative feedback effects, namely the impact of stomatal opening variation on crop transpiration rate (Jarvis and McNaughton, 1986; Aubinet et al., 1989), crop water status (transpiration and stomatal conductance), and production and quality characteristics (Abdel-Mawgoud et al., 1996). All these factors have to be taken into account when searching for the optimal (and time-variable) value of shading intensity. Considering the complexity of the mechanisms and the high number of interactions, the challenge is difficult, but might be met because the understanding and modeling of the coupling mechanisms between outside-inside atmospheres and canopy-inside atmosphere markedly progressed in the last decades. Furthermore, models that account for the various physical and physiological feedback mechanisms prevailing in the greenhouse system (Gonzalez-Real and Baille, 2001) could provide more insight into the influence of shading intensity on crop production.

\section{Greenhouse Energy Balance}

Seginer (1997) noted that $\varepsilon$ ranges between 0 and 1 , with the value of 1 representing "rich vegetation in desert conditions." The higher the value of the evaporation coefficient is, the lower the needs for greenhouse cooling are. Values of the evaporation coefficient near 1 indicate that there is no need for extra cooling since canopy transpiration is sufficient to counteract the heat load and maintain suitable humidity levels for optimum physiological status of the crop (Seginer, 1997; Katsoulas et al., 2006). Baille et al. (1994) calculated $\varepsilon$ values between 0.50 and 0.75 in a hydroponic rose crop grown in Southern France. Similar values (0.60-0.70) were also reported by Boulard et al. (1991) for a tomato crop in the same area.

Generally, low values in the $\varepsilon$ coefficient correspond to high solar energy loads in the greenhouse $\left(R_{\mathrm{s}, \mathrm{i}} \approx 700 \mathrm{~W} \mathrm{~m}^{-2}\right)$ (Katsoulas et al., 2002) which may be not compensated for by crop transpiration. As a result, the plants encounter stress conditions caused by the extreme greenhouse microclimate. This is clearly the case that has to be avoided when growing 
greenhouse crops during summer. The $\varepsilon$ values calculated for the spring period using the greenhouse energy balance method were close to 0.3 for all three greenhouses. This level indicates that transpiration was insufficient to eliminate adverse effects of excessively high solar radiation levels on crop performance and reduce the need for greenhouse cooling. This could be partially attributed also to the fact that the crop had a relatively low leaf area $\left[I_{\mathrm{LA}} \sim 1.5 \mathrm{~m}^{2}\right.$ (leaf) $\mathrm{m}^{-2}$ (ground)]. Thus, it is reasonable to conclude that under summer conditions in the area Velestino-Volos, shading up to $50 \%$ and natural ventilation are insufficient measures to maintain optimum greenhouse microclimate for cucumber plant growth when the plant density is up to 2.4 plants $\cdot \mathrm{m}^{-2}$. Accordingly, it is necessary either to expand the crop leaf area by increasing plant density, thereby enhancing evaporative cooling by crop transpiration (Katsoulas et al., 2002) or to introduce an evaporative cooling system (Katsoulas et al., 2001) to further reduce the energy load caused by excess solar radiation. Nevertheless, a plant density of 2.4 plants $\cdot \mathrm{m}^{-2}$ is considered relatively high for greenhouse cucumber and a further increase may reduce light interception by individual plants, thereby decreasing the mean size and the overall quality of the fruit (Papadopoulos, 1994).

The differences between the $\varepsilon$ values calculated by the two methods (19\% lower values of $\varepsilon$ when using eq. 3 rather than eq. 1) are possibly due to the many factors required for the implementation of greenhouse energy balance using equation 1 as compared to equation 3. Application of equation 3 requires measurements of crop transpiration rate which is not feasible in most commercial greenhouses. Hence, the energy balance method could be considered an easily applicable tool to estimate $\varepsilon$, even if it requires some greenhouse-related characteristic constants, and assess the effectiveness of cooling systems to improve the greenhouse microclimate under hot weather conditions.

\section{Conclusion}

From the growers' point of view, one of the main problems when using shading for alleviating the greenhouse heat load is the right decision on the intensity of shading and the correct timing of shading application. The analysis of greenhouse microclimate and crop production data showed that under Mediterranean conditions, shading is necessary with intensity no higher than $35 \%$ to $40 \%$.

From the engineering point of view, it could be noted that solar radiation decrease due to shading by shade nets does not always involve a notable air temperature and vapor pressure deficit decrease, especially when the ventilation rates are low. Analysis of greenhouse energy balance showed that shading up to $50 \%$ and natural ventilation are not always sufficient measures to maintain optimum greenhouse microclimate for cucumber growth when the plant density is up to 2.4 plants $\cdot \mathrm{m}^{-2}$ and leaf area index is low. Accordingly, it is necessary either to expand the crop leaf area by increasing plant density, thereby increasing evaporative cooling by crop transpiration or to introduce an evaporative cooling system to further reduce the energy load caused by excess solar radiation, with the first option being costless.

\section{REFERENCES}

Abdel-Ghany, A. M., and I. M. Al-Helal. 2010. Characterization of solar radiation transmission through plastic shading nets. Solar En. Materials \& Solar Cells 94(8): 1371-1378.

Abdel-Mawgoud, A. M. R., S. O. El-Abd, S. M. Singer, A. F. Abou-Hadid, and T. C. Hsiao. 1996. Effect of shade on the growth and yield of tomato plants. Acta Hortic. 434(1): 313-320.

ASAE Standards. 2003. ANSI/ASAE EP406.4: Heating, ventilating and cooling greenhouses. St. Joseph, Mich.: ASAE.

Aubinet, M., J. Deltour, and D. De Halleux. 1989. Stomatal regulation in greenhouse crops: Analysis and simulation. Agric. For. Meteorol. 48(1-2): 21-44.

Baille, A., C. Kittas, and N. Katsoulas. 2001. Influence of whitening on greenhouse microclimate and crop energy partitioning. Agric. For. Meteorol. 107(4): 193-306.

Baille, M., A. Baille, and D. Delmon. 1994. Microclimate and transpiration of greenhouse rose crops. Agric. For. Meteorol. 71(1-2): 83-97.

Baille, M., M. Mermier, J. C. Laury, and D. Delmon. 1980. Le point sur les systemes d'ombrage sous serre. Internal Report M/801. INRA, Station de Bioclimatologie d'Avignon, Montfavet.

Bakker, J. C. 1989. The effects of temperature on flowering, fruit set and fruit development of glasshouse sweet pepper (Capsicum annuum L.). J. Hort. Sc. 64(3): 313-320.

Bakker, J. C. 1990. Effects of day and night humidity on yield and fruit quality of glasshouse tomatoes. J. Hort. Sc. 65(3): 323-331.

Bakker, J. C., G. W. H. Welles, and J. A. M. van Uffelen. 1987. The effects of day and night humidity on yield and quality of glasshouse cucumbers. J. Hort. Sc. 62(3): 363-370.

Barradas, V. L., E. Nicolás, A. Torrecillas, and J. J. Alarcón. 2005. Transpiration and canopy conductance of young apricot (Prunus armeniaca $L$.) trees subjected to different PAR levels and water stress. Agric. Wat. Manag. 77(1-3): 323-333.

Boulard, T., A. Baille, and F. Le Gall. 1991. Etude de différentes méthodes de refroidissement sur le climat et la transpiration de tomates de serre (Study of various cooling methods and their effect on microclimate and transpiration of a greenhouse tomato crop). Agronomie 11(7): 543-554.

Boulard, T., and A. Baille. 1993. A simple greenhouse climate control model incorporating effects of ventilation and evaporative cooling. Agric. For. Meteorol. 65(3-4): 145-157.

Boulard, T., P. Feuilloley, and C. Kittas. 1997. Natural ventilation performance of six greenhouse and tunnel types. J. Agric. Eng. Res. 67(4): 249-266.

Bulder, H. A. M, P. H. R. Van Hasselt, and P. J. C. Kuiper. 1987. The effect of temperature on early growth of cucumber genotypes differing in genetic. Adaptation to low-energy conditions. Sci. Hort. 31(1-2): 53-60.

Campbell, G. S. 1986. An Introduction to Environmental Biophysics. New York, N.Y.: Springer-Verlag.

Castellano, S., G. M. Scarascia, G. Russo, D. Briassoulis, A. Mistriotis, S. Hemming, and D. Waaijenberg. 2008. Plastic nets in agriculture: A general review of types and applications. Applied Eng. in Agric. 24(6): 799-808.

Cohen, S., E. Raveh, Y. Li, A. Grava, and E. E. Goldschmidh. 2005. Physiological response of leaves, tree growth and fruit yield of grapefrui trees under reflective shading screens. Sci. Hort. 107(1): 15-35.

El-Aidy, F. 1986. Tomato production under simple protective tunnels in Egypt. Acta Hort. 190(2): 511-514.

El-Gizawy, A. M., M. M. F. Abdallah, H. M. Gomaa, and S. S. Mohamed. 1993. Effect of different shading levels on tomato plants 2: Yield and fruit quality. Acta Hort. 323(1): 349-354.

Fernandez-Rodriguez, E. J., J. Fernandez-Vadillos, F. Camacho-Ferre, J. J. Vazquez, and A. Kenig. 2000. Radiative field uniformity under shading screens under greenhouse versus whitewash in Spain. Acta Hort. 534(1): 125-130. 
González-Real, M. M., and A. Baille. 2001. Simulating the physiological behaviour of a greenhouse rose crop in response to climate manipulations by means of a model including physical and physiological feedbacks. Acta Hort. 559(1): 441-448.

Growers Books. 1980. Cucumbers. Grower Guide No. 15. London, UK: Grower Books.

Heuvelink, E. 1996. Tomato growth and yield: qualitative analysis and synthesis. PhD thesis. Wageningen, The Netherlands: Wageningen Agricultural University.

Jarvis, P. G., and K. G. McNaughton. 1986. Stomatal control of transpiration: scaling up from leaf to region. Advances Ecol. Res. 15(1): 3-50.

Katsoulas, N., A. Baille, and C. Kittas. 2001. Effect of misting on transpiration and conductances of a greenhouse rose canopy. Agric. For. Meteorol. 106(3): 233-247.

Katsoulas, N., A. Baille, and C. Kittas. 2002. Influence of leaf area index on canopy energy partitioning and greenhouse cooling requirements. Bios. Eng. 83(3): 349-359.

Katsoulas, N., C. Kittas, I. L. Tsirogiannis, E. Kitta, and D. Savvas. 2007. Greenhouse microclimate and soilless pepper crop production and quality as affected by a fog evaporative cooling system. Tran. ASABE 50(5): 1831-1840.

Katsoulas, N., D. Savvas, I. L. Tsirogiannis, O. Merkouris, and C. Kittas. 2009. Response of an eggplant crop grown under Mediterranean summer conditions to greenhouse cooling. Sci. Hort. 123(1): 90-98.

Katsoulas, N., T. Bartzanas, T. Boulard, M. Mermier, and C. Kittas. 2006. Effect of vent openings and insect screens on greenhouse ventilation. Bios. Eng. 93(4): 427-436.

Kitao, M., T. T. Lei, T. Koike, H. Tobita, and Y. Maruyama. 2000. Susceptibility to photoinhibition of three deciduous broadleaf tree species with different successional traits raised under various light regimes. Plant Cell and Env. 23(1): 81-89.

Kittas, C., A. Baille, and P. Giaglaras. 1999. Influence of covering material and shading on the spectral distribution of light in greenhouses. J. Agric. Eng. Res. 73(4): 341-351.

Kittas, C., J. P. Chiapale, O. de Villele, and F. Aries. 1987. Paramètres significatifs du déterminisme de la température de l'air de la serre (Significant parameters affecting the greenhouse air temperature). Agric. For. Meteorol. 40(3): 265-277.

Kittas, C., T. Boulard, and G. Papadakis. 1997. Natural ventilation of a greenhouse with ridge and side openings, sensitivity to temperature and wind effects. Tran. ASAE 40(2): 415-425.

Kittas, C., T. Boulard, M. Mermier, and G. Papadakis. 1996. Wind induced air exchange rates in a greenhouse tunnel with continuous side openings. J. Agric. Eng. Res. 65(1): 37-49

Klieber, A., W. C. Lin, P. A. Jolliffe, and J. W. Hall. 1993. Training systems affect canopy light exposure and shelf life of long English cucumber. J. ASHS 118(6): 786-790.

Leonardi, C., S. Guichard, and N. Bertin. 2000. High vapor pressure deficit influences growth, transpiration and quality of tomato fruits. Sci. Hort. 84(3-4): 285-296.

Li, S., N. C. Rajapakse, R. E. Young, and R. Oi. 2000. Growth responses of chrysanthemum and bell pepper transplants to photoselective plastic films. Sci. Hort. 84(3-4): 215-225.

Lorenzo, P., M. L. Garcia, M. C. Sanchez-Guerro, E. Medrano, I. Caparros, and M. Giménez. 2006. Influence of mobile shading on yield, crop transpiration and water use efficiency. Acta Hort. 719(1): 471-478.

Marcelis, L. F., E. Heuvelink, L. R. Hofman-Eijer, J. D. Bakker, and L. B. Xue. 2004. Flower and fruit abortion in sweet pepper in relation to source and sink strength. J. Exp. Bot. 55(406): 2261-2268.

Mashonjowa, E., F. Ronsse, T. Mhizha, J. R. Milford, R. Lemeur, and J. G. Pieters. 2010. The effects of whitening and dust accumulation on the microclimate and canopy behavior of rose plants (Rosa hybrida) in a greenhouse in Zimbabwe. Solar En. 84(1): 10-23.
Monteith, J. L. 1973. Principles of Environmental Physics. London, UK: Contemporary Biology, Edward Arnold.

Naraghi, M., and M. Lotfi. 2010. Effect of different levels of shading on yield and fruit quality of cucumber (Cucumis sativus). Acta Hort. 871(1): 385-388.

Ögren, E., and J. R. Evans. 1992. Photoinhibition of photosynthesis in situ in six species of Eucalyptus. Austral. J. Pl. Physiol. 19(3): 223-232

Olympios, C. M., and J. J. Hanan. 1992. The effect of temperature, humidity and carbon dioxide enrichment in raising cucumbers (Cucumis sativus) seedlings. Acta Hort. 303(1): 105-112.

Papadopoulos, A. P. 1994. Growing greenhouse seedless cucumbers in soil and in soilless media. Agriculture and Agri-Food Canada, Publication 1902/E.

Raveh, E., S. Cohen, T. Raz, A. Grava, and E. E. Goldschmidt. 2003. Increased growth of young citrus trees under reduced radiation load in a semi-arid climate. J. Exp. Bot. 54(381): 365-373.

Romacho, I., O. Hita, T. Soriano, M. I. Morales, I. Escobar, E. M. Suarez-Rey, J. Hernandez, and N. Castilla. 2006. The growth and yield of cherry tomatoes in net covered greenhouses. Acta Hort. 719(2): 529-534.

Rosati, A., F. W. Badeck, and T. M. Dejong. 2001. Estimating canopy light interception and absorption using leaf mass per unit leaf area in Solanum melongena. Annals of Bot. 88(1): 101-109.

Roy, J. C., T. Boulard, C. Kittas and S. Wang. 2002. Convective and ventilation transfers in greenhouses, Part 1: The greenhouse considered as a perfectly stirred tank. Biosyst. Eng. 83(1): 1-20.

Seginer, I. 1997. Alternative design formulae for the ventilation rate of greenhouses. J. Agric. Eng. Res. 68(4): 355-365.

Seginer, I. 2002. The Penman-Monteith evapotranspiration equation as an element in greenhouse ventilation design. Bios. Eng. 82(4): 423-439.

Smith, I. E., M. J. Savage, and P. Mills. 1984. Shading effects on greenhouse tomatoes and cucumbers. Acta Hort. 148(1): 229-237.

Stirzaker, R. J., P. T. Hayman, and B. G. Sutton. 1997. Misting of tomato plants improves leaf water status but not leaf growth. Austral. J. Pl. Physiol. 24(1): 9-16.

Teitel, M., and I. Segal. 1995. Net thermal radiation under shading screens. J. Agric. Eng. Res. 61(1): 19-26.

Wang, S., and T. Boulard. 2000. Measurement and prediction of solar radiation distribution in full-scale greenhouse tunnels. Agronomie. 20(1): 41-50.

Willits, D. H. 2001. The effect of cloth characteristics on the cooling performance of external shade cloths for greenhouses. J. Agric. Eng. Res. 79(3): 331-340.

Yang, X., T. H. Short, D. F. Robert, and W. L. Bauerle. 1990. Transpiration, leaf temperature and stomatal resistance of a cucumber crop. Agric. For. Meteorol. 51(3-4): 197-209.

\section{NOMENCLATURE}

$A_{\mathrm{T}} \quad$ ventilation area $\left(\mathrm{m}^{2}\right)$

$A_{\mathrm{v}} \quad$ area of greenhouse vertical section $\left(\mathrm{m}^{2}\right)$

$C_{\mathrm{d}}$ discharge coefficient (dimensionless)

$C_{\mathrm{p}} \quad$ specific heat of air at constant pressure $\left[\mathrm{J} \mathrm{kg}^{-1}\right.$ (air) $\left.\mathrm{K}^{-1}\right]$

$C_{\mathrm{w}}$ global wind-effect coefficient of ventilation (dimensionless)

$d \quad$ characteristic leaf length (m)

$e \quad$ vapor pressure $(\mathrm{kPa})$

$E_{\mathrm{c}} \quad$ crop transpiration rate $\left(\mathrm{kg} \mathrm{m}^{-2} \mathrm{~s}^{-1}\right)$

$g_{\mathrm{a}} \quad$ crop aerodynamic conductance $\left(\mathrm{mm} \mathrm{s}^{-1}\right)$

$I_{\mathrm{LA}}$ leaf area index $\left[\mathrm{m}^{2}\right.$ (leaf) $\mathrm{m}^{-2}$ (ground)]

$Q \quad$ greenhouse ventilation rate $\left(\mathrm{m}^{3} \mathrm{~s}^{-1}\right)$

$Q_{0} \quad$ leakage ventilation rate $\left(\mathrm{m}^{3} \mathrm{~s}^{-1}\right)$ 
$R_{\mathrm{S}, \mathrm{i}} \quad$ incoming solar radiation $\left(\mathrm{W} \mathrm{m} \mathrm{m}^{-2}\right)$

$R_{\mathrm{S}, \mathrm{o}}$ outside solar radiation $\left(\mathrm{W} \mathrm{m}^{-2}\right)$

$T$ temperature $\left({ }^{\circ} \mathrm{C}\right)$

$T_{\mathrm{e}} \quad$ exhaust air temperature considered equal to greenhouse air temperature $T_{\mathrm{i}}\left({ }^{\circ} \mathrm{C}\right)$

$T_{\mathrm{i}} \quad$ mean air temperature $\left({ }^{\circ} \mathrm{C}\right)$

$T_{\mathrm{O}} \quad$ outside air temperature $\left({ }^{\circ} \mathrm{C}\right)$

$U$ heat transfer coefficient through the cover $\left(\mathrm{W} \mathrm{m}^{-2} \mathrm{~K}^{-1}\right)$

$u_{\mathrm{i}} \quad$ air velocity inside the greenhouse $\left(\mathrm{m} \mathrm{s}^{-1}\right)$

$u_{\mathrm{o}} \quad$ outside air velocity $\left(\mathrm{m} \mathrm{s}^{-1}\right)$
$V P D_{\mathrm{i}}$ outside air vapor pressure deficit $(\mathrm{kPa})$

$V P D_{\mathrm{O}}$ outside air vapor pressure deficit $(\mathrm{kPa})$

$\varepsilon \quad$ evaporation coefficient (dimensionless)

$\lambda$ latent heat of vaporization of water [ $\mathrm{J} \mathrm{kg}^{-1}$ (vapor)]

$\lambda E_{\mathrm{c}}$ transpiration rate $\left\{\mathrm{W} \mathrm{m}^{-2}\right.$ (ground covered by crop)]

$\rho \quad$ air density [ $\mathrm{kg}$ (air) $\mathrm{m}^{-3}$ (air)]

$\tau$ greenhouse transmission coefficient to solar radiation (dimensionless) 